\title{
Sowing Depths and Nut Sizes Effects on Seedling Emergence and Growth of Cashew (Anacardium occidentale L.)
}

\author{
E. A. Adeyemi ${ }^{1 *}$, H.Tijani-Eniola ${ }^{2}$ and O. S. Ibiremo ${ }^{1}$ \\ ${ }^{1}$ Cocoa Research Institute of Nigeria, Ibadan, Nigeria. \\ ${ }^{2}$ Department of Agronomy, University of Ibadan, Nigeria.
}

Authors' contributions

This work was carried out in collaboration between all authors. All authors read and approved the final manuscript.

Article Information

DOI: $10.9734 /$ IJPSS/2017/10436

Editor(s):

(1) Sachin Rustgi, Department of Crop \& Soil Sciences, Washington State University, Pullman, WA-99164, USA. (2) Francisco Cruz-Sosa, Biotechnology Department, Metropolitan Autonomous University Iztapalapa Campus, Av. San Rafael

Atlixco 186 México City 09340 México.

Reviewers:

(1) Felix M. Chipojola, Ministry of Agriculture and Food Security, Malawi.

(2) R. K. Upadhyay, D. D. U. Gorakhpur University, Gorakhpur, India.

(3) Olubunmi Aina, University of Florida, USA.

Complete Peer review History: http://www.sciencedomain.org/review-history/19789

Original Research Article

Received $28^{\text {th }}$ March 2014

Accepted $20^{\text {th }}$ February 2017

Published $30^{\text {th }}$ June 2017

\begin{abstract}
Damage on aerial cotyledons from emerging cashew (Anacardium occidentale L.) by rodents severely affects seedling establishment in the field. The objective of this study was to evaluate sowing depth of cashew as a possible means of reducing pest attack and damage to seedlings during establishment via in-situ sowing. The study was conducted under shade of Gliricidia sepium trees at the Cocoa Research Institute of Nigeria (CRIN) central nursery, using two nut sizes: jumbo $(\geq 16 \mathrm{~g})$ and medium $(6-8 \mathrm{~g})$ and five sowing depths: $5.0,7.5,10.0,12.5$ and $15.0 \mathrm{~cm}$ in 2005; 2.5, 5.0, 7.5, 10.0 and 12.5 in 2006. The treatments were arranged in a randomized complete block design (RCBD) with four replications. Data were collected on days to emergence, percentage emergence, position of cotyledons (above or below soil level), plant height, stem diameter and analyzed using ANOVA. Means were separated using least significant difference (LSD). Jumbo and medium nuts emerged at similar periods (22 and 21days respectively). Depth of sowing enhanced both the rate and total emergence. Nuts sown at $2.5 \mathrm{~cm}$ emerged 12 days earlier and $22 \%$ higher in emergence than those sown at $12.5 \mathrm{~cm}$ depth. The difference was significant $(P=.05)$. Similarly,
\end{abstract}


seedling emergence was earlier for cashew nut sown at $5.0 \mathrm{~cm}$ compared to those sown at 12.5 and $15.0 \mathrm{~cm}$ depths with significant $(P=.05)$ difference. Seedling emergence, growth and cotyledon concealment were in the order of $7.5>10.0>12.5 \mathrm{~cm}$ for the two nut sizes. The cashew seedling height and stem diameter were higher in jumbo-size nut seedlings than in medium-size with significant $(P=.05)$ difference. Sowing at $7.5 \mathrm{~cm}$ soil depth gave the best performance in terms of seedling protection and growth. Jumbo nut size may be preferred by farmers to medium size in terms of initial seedling growth performance.

Keywords: Cashew; nuts sizes; seedling; cotyledons; sowing depth.

\section{INTRODUCTION}

Cashew is a fast growing plant that is adaptable to a varying degree of edapic and climatic conditions. Hence, cashew thrives under environmental situations where most other plants such as cacao will not survive. It is well reputed for being drought resistant and sufficiently adaptable to areas with rainfalls ranging between $500 \mathrm{~mm}$ to $3800 \mathrm{~mm}[1,2]$. Presently, cashew is grown in most agro-ecological zones of Nigeria including the savanna areas [3,4]. Adenikinju [5] reported that cashew grows in the mangrove forest areas but its productivity is limited in terms of nut yield. It is however at its best in the middle belt savanna zone where the environment favours nut production.

Field establishment of cashew could be done through nuts (seeds) or seedlings. However the former (sowing at stake /in-situ) is preferred by most farmers since seedlings do not transplant well due to its delicate root system [6]. Sowing of cashew in-situ is a practice among cashew farmers, in countries like Nigeria, Tanzania and Ghana, in the establishment of both smallholdings and large plantations $[7,8,9]$. The Advantages of this practice, as reported by Ohler [10], include: quick development of the root systems; less costs involved and labour saving. The danger inherent in this method is the possibility of damage of seedlings by animals such as rodents, reptiles, monkeys that are attracted by the succulent and sugary cotyledons of the seedlings [2]. Gauze collar wires are usually used to protect seedlings against destruction by the vamine including bush pigs. Rodenticides have been tried and found to be satisfactory. These measures may not be cost effective and affordable to the many poorresource Nigerian farmers. The objective of this study was to determine the sowing depth that promotes emergence and seedling growth as well as conceal seedling cotyledons in the soil so as to prevent destruction of seedling by rodents and other pests.

\section{MATERIALS AND METHODS}

The study was carried out at the Cocoa Research Institute of Nigeria (CRIN), Ibadan ( $7^{\circ}$ $10 \mathrm{~N}$; 352E). Ibadan lies within the forest savanna transitional zone of Southern Nigeria. During the study period (2005-2006), average rainfall and relative humidity were $1205 \mathrm{~mm}$ and $88.4 \%$, respectively. The maximum and minimum prevailing temperatures were 27.8 and $24^{\circ} \mathrm{C}$ as respectively.

The soil used for the study was collected at a site that has been earmarked for cashew cultivation on the CRIN Estate, at a depth of $0-30 \mathrm{~cm}$ using soil auger. The soil was air-dried for 2 weeks and sieved with $5 \mathrm{~mm}$ sieve. A representative sample was taken and further processed for physical and chemical analysis. Plastic pots of $7.5 \mathrm{~L}$ capacity were filled with the processed soil and arranged under shade of Gliricidia sepium trees in CRIN central nursery.

Freshly harvested cashew nuts from the Brazilian selections were used for the study. Treatments included cashew nut sizes: jumbo ( $\geq 16 \mathrm{~g}$ per nut) and medium (6-8 g), and sowing depths of $5.0,7.5,10.0,12.5$ and $15.0 \mathrm{~cm}$ in 2005 as well as 2.5, 5.0, 7.5, 10.0 and $12.5 \mathrm{~cm}$ in 2006. One nut was sown per pot and the treatments were replicated four times. The treatments were arranged in a randomized complete block design. Watering was done thrice a week for a period of twelve months, while weeding was done at a month interval.

Emergence count of the nuts was recorded daily as well as the position of the cotyledon either above or below soil level. Growth parameters (plant height and stem diameter) were measured at 8, 11 and 14 weeks after sowing (WAS). Data were analyzed using ANOVA. Means were separated using the LSD at $5 \%$ level of probability. 


\section{RESULTS AND DISCUSSION}

The physical properties of the soil indicated that the sand, silt and clay fractions were respectively 692,134 and $174 \mathrm{~g} / \mathrm{kg}$ soil (Table 1). The clay + silt content of $308 \mathrm{~g} / \mathrm{kg}$ soil were sufficient to hold enough moisture for sustainable cashew growth and to avoid drought [9]. The $\mathrm{pH}$, organic carbon, total $\mathrm{N}$ and available $\mathrm{P}$ were $7.65,1.73 \mathrm{~g} / \mathrm{kg}, 0.42$ $\mathrm{g} / \mathrm{kg}$ and $11.08 \mathrm{mg} / \mathrm{kg}$ soil respectively. The exchangeable cations $\left(\mathrm{K}^{+}, \mathrm{Ca}^{2+}\right.$ and $\left.\mathrm{Mg}^{2+}\right)$ of the soil were $0.10,1.03$ and $0.45 \mathrm{cmol} / \mathrm{kg}$ soil. The soil is sandy loam. The $\mathrm{pH}$ of the soil was adequate for cashew production. The soil is marginal in terms of nutrient compositions particularly $\mathrm{N}, \mathrm{P}$ and $\mathrm{K}$, but could support the growth of cashew $[4,11,12]$.

\section{Table 1. Initial physical and chemical} properties of the soil used

\begin{tabular}{ll}
\hline Soil property & Values \\
\hline $\mathrm{N}(\mathrm{g} / \mathrm{kg})$ & 0.42 \\
$\mathrm{OC}(\mathrm{g} / \mathrm{kg})$ & 1.73 \\
$\mathrm{pH}\left(\mathrm{H}_{2} \mathrm{O}\right)$ & 7.65 \\
$\mathrm{pH}(\mathrm{KCl})$ & 6.89 \\
$\mathrm{P}(\mathrm{mg} / \mathrm{kg})$ & 11.08 \\
$\mathrm{Na}$ & 0.08 \\
$\mathrm{~K}(\mathrm{cmol} / \mathrm{kg})$ & 0.10 \\
$\mathrm{Ca}(\mathrm{cmol} / \mathrm{kg})$ & 1.03 \\
$\mathrm{Mg}(\mathrm{Cmol} / \mathrm{kg})$ & 0.45 \\
$\mathrm{Cu}(\mathrm{mg} / \mathrm{kg})$ & 57.44 \\
$\mathrm{Mn}(\mathrm{mg} / \mathrm{kg})$ & 151.09 \\
$\mathrm{Fe}(\mathrm{mg} / \mathrm{kg})$ & 98.88 \\
$\mathrm{Zn}(\mathrm{mg} / \mathrm{kg})$ & 71.68 \\
Sand $(\mathrm{g} / \mathrm{kg})$ & 692 \\
Silt $(\mathrm{g} / \mathrm{kg})$ & 174 \\
Clay $(\mathrm{g} / \mathrm{kg})$ & 134 \\
\hline
\end{tabular}

\subsection{Days to Emergence of Seedling}

Days to seedling emergence were more in jumbo than in medium size nuts in both years (Table 2). This is in agreement with the previous findings where medium size nuts emerged earlier than jumbo [13]. The food reserve in the cotyledons of jumbo is more than in medium due to the bigger size of the former. Consequently, the more days for this food reserve to metabolise before seedling emerges may be responsible for the more days to seedling emergence in jumbo than in medium.

The mean number of days for the emergence of jumbo and medium size nuts were 30 and 27 days in 2005 respectively.
Among the 5 sowing depths investigated, days to emergence ranged between 23 and 44. Seedling emergence was significantly $(P=.05)$ earlier for cashew nut sown at shallow depths $(5.0,7.5$, and $10.00 \mathrm{~cm}$ ) than those sown at deeper depth (15.0 $\mathrm{cm})$. Specifically, nuts sown at $5.0 \mathrm{~cm}$ depth had significantly $(P=.05)$ improved emergence than those sown at $12.5 \mathrm{~cm}$. In the latter case the deeper sowing depths delayed seedling emergence. As a result of the shallow depth of sowing at $2.5-7.5 \mathrm{~cm}$ the emerging seedlings had sufficient force to push through the soil to the surface while deeper sowing depths $(10.0-12.5$ $\mathrm{cm}$ ) impede seedling emergence as reported by Parker and Taylor [14] and Rao et al. [15]. Similarly, Li [16] observed that deep sowing increase time of emergence in American ginseng. There was no significant interaction between sowing depths and nut sizes (Table 2).

In 2006, similar trend was observed as in 2005 with jumbo-size nut which took longer days to emerge. Mean days to seedling emergence were 22 and 21 for jumbo and medium-size nuts respectively (Table 2). The difference in days to seedling emergence in the two nut sizes was not significant as was observed in 2005. Mean days to emergence of nuts sown at $2.5 \mathrm{~cm}$ depth was shorter compared to those sown at $12.5 \mathrm{~cm}$ and the difference was significant $(P=.05)$. Sowing depths of $5.0,7.5$ and $10.0 \mathrm{~cm}$ were similar in mean days to seedling emergence in both years.

\subsection{Percent Seedling Emergence}

The percent emergence ranged from 25 to 62 for both jumbo and medium sized nuts and across the various sowing depths in 2005 while in 2006, it was 33 to 75 (Table 2). The level of seedling emergence increased by $39 \%$ in 2006 compared to 2005. The increase might be due to the viability status of the nuts as at the time of sowing. It could be that some of the nuts planted in 2005 might not have been viable as those planted in 2006 probably due to immature kernel (Adeyemi and Hammed [17]). Percent seedling emergence from $2.5 \mathrm{~cm}$ to $7.5 \mathrm{~cm}$ sowing depths was higher than those sown at deeper depths in both 2005 and 2006 (Table 2). This finding is consistent with the earlier reports where it was observed that too deep sowing reduced seedling emergence in okra and ginseng respectively $[18,16]$. This may be due to the fact that seedlings planted at shallower depths might find it much easier to emerge from the soil than those at deeper depths. Deeper sowing renders seedling more susceptible to attack by pathogens [19]. 
Table 2. Emergence of cashew nuts as influenced by sowing depths and nut sizes

\begin{tabular}{|c|c|c|c|c|c|c|c|c|}
\hline \multirow[t]{3}{*}{ Depth (cm) } & \multicolumn{4}{|c|}{2005} & \multicolumn{4}{|c|}{2006} \\
\hline & \multicolumn{2}{|c|}{ Days to emergence } & \multicolumn{2}{|c|}{$\%$ emergence } & \multicolumn{2}{|c|}{$\begin{array}{c}\text { Days to } \\
\text { emergence }\end{array}$} & \multicolumn{2}{|c|}{$\%$ emergence } \\
\hline & Ju & Me & Ju & Me & Ju & Me & Ju & Me \\
\hline 2.5 & na & na & na & na & 18.5 & 15.8 & 75.0 & 68.8 \\
\hline 5.0 & 23.3 & 25.7 & 56.3 & 33.3 & 20.2 & $20 ; 7$ & 62.5 & 66.7 \\
\hline 7.5 & 28.0 & 25.0 & 58.3 & 62.5 & 20.5 & 20.0 & 56.3 & 62.5 \\
\hline 10.0 & 31.0 & 28.0 & 41.7 & 25.0 & 22.5 & 22.0 & 56.3 & 56.3 \\
\hline 12.5 & 36.3 & 28.3 & 33.3 & 41.7 & 29.3 & 28.0 & 33.3 & 66.7 \\
\hline 15.0 & 44.0 & 36.0 & 25.0 & 25.0 & na & na & na & $\mathrm{Na}$ \\
\hline Means & 30.1 & 27.3 & 46.4 & 41.1 & 22.8 & 21.0 & 57.9 & 63.9 \\
\hline \multicolumn{9}{|l|}{ LSD: } \\
\hline Depths & & 8.7 & & 27.6 & & 3.0 & & 21.3 \\
\hline Sizes & & 4.9 & & 15.6 & & 1.9 & & 13.4 \\
\hline$D \times S$ & & 12.3 & & 39.1 & & 4.2 & & 30.2 \\
\hline Depths & & * & & ns & & $* \star \star$ & & $\mathrm{Ns}$ \\
\hline Sizes & & ns & & ns & & ns & & Ns \\
\hline$D \times S$ & & ns & & ns & & ns & & Ns \\
\hline 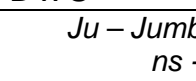 & 3 & & fican & $\begin{array}{l}\text { owing } \\
=.05 \text { ) }\end{array}$ & & $\begin{array}{l}\text { ut } \\
\text { nifica }\end{array}$ & $\begin{array}{l}t a \\
0.0\end{array}$ & \\
\hline
\end{tabular}

There was no significant interaction between sowing depths and nut sizes in both years. However, shallow sowing seems to favour seedling emergence irrespective of the sizes of the nuts.

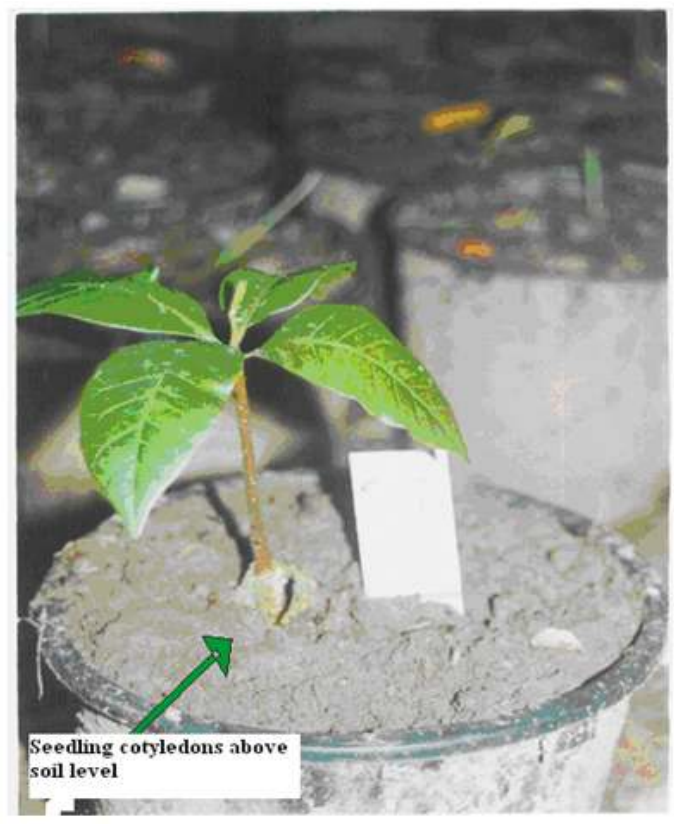

Plate 1. Cashew nut sown at $2.5 \mathrm{~cm}$ depth positioned seedling cotyledons above soil level

\subsection{Position of Seedling Cotyledons}

It was observed that in all the treatments, cotyledons were either buried or raised above the soil surface (Table 3). In 2005 and 2006, the nut sizes did not significantly affect the position of the cotyledons but sowing depths at $7.5 \mathrm{~cm}$ and above had the cotyledons buried in the soil. [20] reported that deep sowing of peanut retained the cotyledons inside the soil. This would protect the cotyledons from attack by predators (reptiles, monkeys, rodents etc). In 2006, jumbo-sized nuts had its cotyledons completely (100\%) exposed at depth of $2.5 \mathrm{~cm}$ (Plate 1), while $25 \%$ seedling cotyledons of medium-sized nuts were exposed at the same depth (Table 3). Sowing at $7.5 \mathrm{~cm}$ and above had the cotyledons buried for both nut sizes (Plate 2). The seedling cotyledons concealment as a result of the sowing depths will make the cashew seedlings survive the threat of predators and there will be no additional cost incurred by farmers to procure chemicals or traps to scare the predators. This will enable the farmers to get the advantage of both protection for the young plants and less production cost since there will be no need for nursery practices and transplanting of seedlings from the nursery to the field with its attendant losses. The physiological implication of the buried cotyledons is that the possibility of using the cotyledons as photosynthetic apparatus may be impaired due to lack of exposure to sunlight. 
Table 3. Placement of cotyledons of cashew seedlings as influenced by sowing depths and nut sizes

\begin{tabular}{|c|c|c|c|c|c|c|c|c|}
\hline \multirow{3}{*}{$\begin{array}{l}\text { Depth } \\
\text { (cm) }\end{array}$} & \multicolumn{4}{|c|}{2005} & \multicolumn{4}{|c|}{2006} \\
\hline & \multicolumn{2}{|c|}{$\begin{array}{c}\text { Cotyledon buried } \\
(\%)\end{array}$} & \multicolumn{2}{|c|}{$\begin{array}{c}\text { Cotyledon not } \\
\text { buried (\%) }\end{array}$} & \multicolumn{2}{|c|}{$\begin{array}{c}\text { Cotyledon buried } \\
(\%)\end{array}$} & \multicolumn{2}{|c|}{$\begin{array}{c}\text { Cotyledon not buried } \\
(\%)\end{array}$} \\
\hline & $\mathrm{Ju}$ & $\mathrm{Me}$ & Ju & $\mathrm{Me}$ & & $\mathrm{Me}$ & Ju & $\mathrm{Me}$ \\
\hline 2.5 & $\mathrm{Na}$ & $\mathrm{na}$ & na & na & 0.0 & 75.0 & 100.0 & 25.0 \\
\hline 5.0 & 75.0 & 100.0 & 25.0 & 0.0 & 62.5 & 75.0 & 37.5 & 25.0 \\
\hline 7.5 & 100.0 & 100.0 & 0.0 & 0.0 & 100.0 & 100.0 & 0.0 & 0.0 \\
\hline 10.0 & 100.0 & 100.0 & 0.0 & 0.0 & 100.0 & 100.0 & 0.0 & 0.0 \\
\hline 12.5 & 100.0 & 100.0 & 0.0 & 0.0 & 100.0 & 100.0 & 0.0 & 0.0 \\
\hline 15.0 & 100.0 & 100.0 & 0.0 & 0.0 & na & na & na & $\mathrm{Na}$ \\
\hline Means & 95.0 & 100.0 & 5.0 & 0.0 & 90.6 & 90.0 & 68.8 & 25.0 \\
\hline $\begin{array}{l}\text { Depth } \\
\text { Depthe }\end{array}$ & & 16.0 & & 0.0 & & 153 & & 47.6 \\
\hline Sizes & & 9.4 & & 0.0 & & 7.2 & & 35.6 \\
\hline$D \times S$ & & 23.5 & & 0.0 & & 16.7 & & 52.1 \\
\hline Depths & & ns & & ns & & ns & & * \\
\hline Sizes & & ns & & ns & & 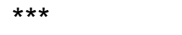 & & Ns \\
\hline$D \times S$ & & ns & & ns & & ns & & Ns \\
\hline & umbo & 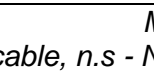 & Nin & 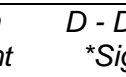 & in & $\begin{array}{l}n g \\
=.05)\end{array}$ & ignif & $\begin{array}{l}\text { of nut } \\
t p \leq 0.001\end{array}$ \\
\hline
\end{tabular}

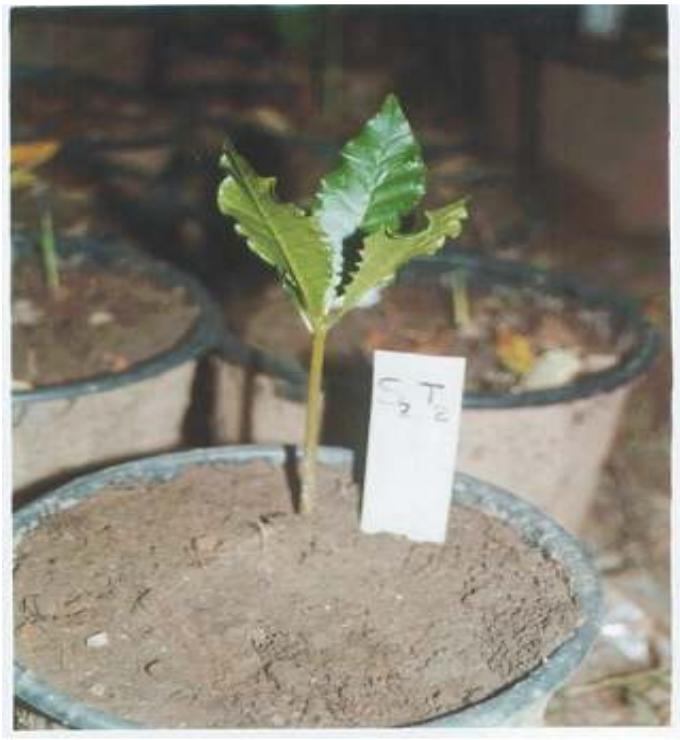

Plate 2. Cashew nut-sowing at $7.5 \mathrm{~cm}$ depth positioned seedling cotyledons below the soil level

\section{THE EFFECT OF NUT SOWING DEPTHS ON GROWTH PARAMETERS OF CASHEW SEEDLINGS AT 8,11 AND 14 WEEKS AFTER SOWING}

\subsection{Seedling Height}

The height of cashew seedlings was significantly $(P=.05)$ higher in jumbo nut than in medium throughout the periods of investigation in 2006 (Table 4). This could be due to differences in the amount of food reserve in the two nut sizes. This is consistent with the findings of [21] and [22] in which large cashew nut sizes had better growth performances than small nuts. Sowing depth of $2.5 \mathrm{~cm}$ significantly produced taller seedlings compared to those planted at $12.5 \mathrm{~cm}$. Plant height reduced with deeper depths throughout the periods of investigation. The higher plant height obtained at 2.5 to $7.5 \mathrm{~cm}$ sowing depths over 10.0 and $12.5 \mathrm{~cm}$ might be due to the shorter period of emergence of the germinated nuts than it was observed at deeper depths.

\subsection{Seedling Stem Diameter}

The stem diameter of cashew seedlings raised from jumbo-size nut was significantly $(P=.05)$ higher than those from medium throughout the period of study in 2006 (Table 5). This might be due to the higher food reserve of the jumbo nuts. This is also consistent with findings of [23] and [24]. Similarly, nuts sown at $2.5 \mathrm{~cm}$ depth produced seedlings with significantly $(P=.05)$ higher stem diameter than those sown at deeper depths. Seedling stem diameter was inversely related to sowing depth. Stem diameter of seedlings sown at 5.0, 7.5 and $10.0 \mathrm{~cm}$ soil depths was similar throughout the period of investigation (Table 5). 
Table 4. Heights of cashew seedlings as influenced by sowing depths and nuts sizes

\begin{tabular}{|c|c|c|c|c|c|c|}
\hline \multirow[t]{3}{*}{ Sowing depth (cm) } & \multicolumn{6}{|c|}{ Seedling heights } \\
\hline & \multirow{2}{*}{$\begin{array}{l}8 \text { WAS } \\
\text { Jumbo }\end{array}$} & \multirow[b]{2}{*}{ Medium } & \multicolumn{2}{|c|}{11 WAS } & \multicolumn{2}{|c|}{14 WAS } \\
\hline & & & Jumbo & Medium & Jumbo & Medium \\
\hline 2.5 & 31.15 & 23.80 & 34.43 & 26.63 & 37.25 & 30.03 \\
\hline 5.0 & 27.63 & 20.33 & 31.93 & 23.50 & 34.25 & 25.85 \\
\hline 7.5 & 25.70 & 22.20 & 29.08 & 25.08 & 32.05 & $26 . .75$ \\
\hline 10.0 & 23.25 & 16.45 & 26.43 & 20.08 & 29.30 & 22.50 \\
\hline 12.5 & 18.33 & 12.33 & 20.33 & 16.50 & 23.33 & 18.27 \\
\hline Means & 25.57 & 19.32 & 28.85 & 22.79 & 31.65 & 24.90 \\
\hline LSD: & & & & & & \\
\hline D & & 5.35 & & 6.41 & & 6.37 \\
\hline S & & 3.36 & & 4.03 & & 4.00 \\
\hline$D \times S$ & & 7.58 & & 9.09 & & 9.03 \\
\hline $\mathrm{D}$ & & $* *$ & & * & & ** \\
\hline $\mathrm{S}$ & & ** & & * & & ** \\
\hline$D \times S$ & & ns & & ns & & ns \\
\hline
\end{tabular}

Table 5. Stem diameter of cashew seedlings in relation to sowing depths and nut sizes

\begin{tabular}{|c|c|c|c|c|c|c|}
\hline \multirow[t]{3}{*}{ Depth (cm) } & \multicolumn{6}{|c|}{ Seedling diameter (mm) } \\
\hline & \multicolumn{2}{|c|}{8 WAS } & \multicolumn{2}{|c|}{11 WAS } & \multicolumn{2}{|c|}{14 WAS } \\
\hline & $\mathrm{Ju}$ & $\mathrm{Me}$ & Ju & $\mathrm{Me}$ & Ju & $\mathrm{Me}$ \\
\hline 2.5 & 6.83 & 5.98 & 8.15 & 6.65 & 8.45 & 7.00 \\
\hline 5.0 & 6.08 & 4.50 & 7.00 & 5.40 & 7.20 & 5.77 \\
\hline 7.5 & 5.30 & 4.88 & 6.43 & 5.53 & 6.68 & 6.05 \\
\hline 10.0 & 5.30 & 4.35 & 5.95 & 5.40 & 6.78 & 5.63 \\
\hline 12.5 & 4.80 & 2.97 & 5.40 & 3.47 & 5.57 & 3.97 \\
\hline Means & 5.66 & 4.06 & 6.65 & 5.38 & 7.10 & 5.77 \\
\hline \multicolumn{7}{|l|}{ LSD: } \\
\hline Depths & & 0.83 & & 0.75 & & 0.83 \\
\hline Sizes & & 0.52 & & 0.47 & & 0.52 \\
\hline$D \times S$ & & 1.18 & & 1.06 & & 1.18 \\
\hline Depths & & $* * *$ & & $\star * * *$ & & $\star \star \star *$ \\
\hline Sizes & & $* *$ & & $* * *$ & & $* \star *$ \\
\hline$D \times S$ & & ns & & ns & & ns \\
\hline
\end{tabular}

Considering the growth performance of the cashew seedlings in term of plants height and stem diameter, it was optimal at 2.5 to $7.5 \mathrm{~cm}$ sowing depths. However, seedling cotyledons were concealed in the soil from predators at 7.5 $\mathrm{cm}$ sowing depth. Therefore, a sowing depth of $7.5 \mathrm{~cm}$ with total burying of cotyledons and optimal growth records would help to achieve the protection of emerging cashew seedlings and guide against pest attack and damages for in-situ planting of cashew in the field. Conclusively, sowing depth of $7.5 \mathrm{~cm}$ was optimal for seedling protection and growth while jumbo nuts may be preferred to medium nuts in terms of growth performance.

\section{CONCLUSION}

The bane in sowing cashew nut in-situ could be surmounted through sowing at $7.5 \mathrm{~cm}$ depth. At this depth, cashew seedling's cotyledons are concealed in the soil at emergence thereby protecting the seedling from predators that are attracted by the cotyledons. With this achievement, costs of nursery operations in the production of seedlings, costs of seedling 
transportation and transplanting to the field are averted. This could lead to a reduction in the cost of cashew plantation establishment for the poor resource Nigerian cashew farmers.

\section{ACKNOWLEDGEMENTS}

The authors hereby acknowledge the Executive Director, Cocoa Research Institute of Nigeria for the permission to publish this work. The comments of the reviewers in improving the write-up are well appreciated.

\section{COMPETING INTERESTS}

Authors have declared that no competing interests exist.

\section{REFERENCES}

1. Anonymous. Soils and climate; 2014. Available:http://www.ikisan.com/Crop\%20 Specific/Eng/links/tn cashewSoilsAndClim ate.shtml

(Accessed on 9 January, 2014)

2. Argles GK. Cashew (Anarcardium occidentale). In: Production of Tropical Crops. 2001;184-220.

3. Topper CP, Caligari PDS, Camara M, Diaora S, Djaha A, Coulibay F, Asante AK, Boamah A, Ayodele EA, Adebola PO. West Africa regional cashew survey report (Guinea, Guinea Bissau, Cote d'lvore, Ghana and Nigeria). Sustainable Tree Crop Programme (STCP) and Biohybrids Agrisystem Ltd. U.K. 2001;1:110.

4. Adewale BD, Ibiremo OS, Odoh NC, Adeyemi EA. Genetic estimates and trend analysis of some growth parameters of cashew (Anacardium occidentale L.) as influenced by nine nutrient combinations. In: Journal of Agricultural Biotechnology and Sustainable Development. 2013; 5(1):6-11.

5. Adenikinju SA. Cashew establishment and maintenance in: National workshop on cashew production technology. CRIN/ NAERLS. 1996;22-27.

6. Azam-Ali SH, Judge EC. Small-scale cashew nut processing; 2001.

Available:www.fao.org/ag/ags/Agsi/cashew /cashew.htm 91

(Accessed on 9 January, 2014)

7. Adenikinju SA, Esan EB, Adeyemi AA. Nursery techniques, propagation and management of cacao, kola, coffee, cashew and tea in: Progress in tree crop research $2^{\text {nd }}$ Ed. CRIN Ibadan. 1989;1-27.

8. Sijaona MER. United Republic of Tanzania: Assessment of the situation and development prospects for the cashew nut sector. International Trade Centre UNCTAD/WTO (ITC). 2002;41.

9. Opoku-Ameyaw K, Amoah FM, Oppong FK, Agene V. Determination of optimum age for transplanting cashew (Anacardium occidentale) seedlings in Northern Ghana. African Journal of Agricultural Research 2007;2(7):296-299.

Available:http://www.academicjournals.org/ AJAR

ISSN: 1991- 637X (C) 2007 Academic Journals.

10. Ohler JG. Cashew. Knninktijk Institute Vorde Tropen, Amsterdam. 1979;260.

11. Egbe NE, Ayodele EA, Obatolu CR. Soils and nutrition of cacao, coffee, kola, cashew and tea in: Progress in tree crop research. $2^{\text {nd }}$ Ed. CRIN, Ibadan. 1989;2838.

12. Adewale BD, Ibiremo OS, Odoh NC, Adeyemi EA. Genetic estimates and trend analysis of some growth parameters of cashew (Anacardium occidentale L.) as influenced by nine nutrient combinations In: Journal of Agricultural Biotechnology and Sustainable Development. 2013; 5(1):6-11.

13. Adeyemi EA, Tijani-Eniola $\mathrm{H}$, Famaye AO. Nut storage periods and nut sizes effects on cashew (Anacardium occidentale L.) seedling emergence and growth. ARPN Journal of Agricultural and Biological Science. 2011;6(7):33-38.

14. Parker JJ, Taylor HM. Soil strength and seedling emergence relations. I. Soil type, moisture tension and planting depth effects. Agron Journal. 1965;57:289-291.

15. Rao VNM, Rao IKS, Hassan MV. Studies on certain aspects of germination of seeds in cashew (Anacardium occidentale L.). India Journal of Agricultural Science. 1975;27:25-34.

16. Li TS. Effect of seeding depth and of soil texture on seedling emergence and root shape of American ginseng. Korean Journal Ginseng Science. 1997;21:115118.

17. Adeyemi EA, Hammed LA. Germination studies of floaters and sinkers of cashew nuts in the nursery. Proceeding of HORTSON. 2003;101-103. 
18. El-Shaikh KA, Mohammed MS. Enhancing fresh and seed yield of okra and reducing chemical phosphorus fertilizer via using VA-mycorrhizal inoculants. World Journal Agric Science. 2009;5:810-818.

19. $\mathrm{Yu} \mathrm{YH}$, Cho DH, Lee IH, Ohh SH. Effect of seeding depth on severity of damping-off ginseng seedlings caused by Rhizoctonia solani. Korean Journal Ginseng Science 1990;14:432-436.

20. Feifei Qin, Hui-lian Xu, Dianqiu Lü, Tetsuo Takano. Responses of hypocotyl elongation to light and sowing depth in peanut seedlings. Journal of Food, Agriculture \& Environment. 2012;10(2): 607-612.

21. Adebola PO, Esan EB, Famaye AO. The effect of nut weight on germination and seedling vigour in cashew $(A$. occidentale L.). Nigeria Journal of Tree Crops Research. 1999;3(2):72-80.

22. Ibiremo OS, Fagbola $\mathrm{O}$, Ogunlade $\mathrm{MO}$, Illoyanomon $\mathrm{Cl}$. Performance of cashew seedlings as influenced by AM fungi inoculations and phosphate fertilizers. The Nigerian Journal of Horticultural Science. 2005;10:47-51.

23. Falade JA. Cashew growing soils in Nigeria. E. African Agric Journal. 1978; 43:100-105.

24. Ibiremo OS, Fagbola O. Growth of cashew as influenced by Arbuscular mycorrhizal inoculations on organic and phosphate fertilizers in Ibadan and Uhonmora, Nigeria. Applied Tropical Agriculture. 2008; 13:(1\&2):64-73.

(0) 2017 Adeyemi et al.; This is an Open Access article distributed under the terms of the Creative Commons Attribution License (http://creativecommons.org/licenses/by/4.0), which permits unrestricted use, distribution, and reproduction in any medium, provided the original work is properly cited.

Peer-review history:

The peer review history for this paper can be accessed here: http://sciencedomain.org/review-history/19789 